\title{
PENGARUH LINGKUNGAN KERJA DAN GAYA KEPEMIMPINAN TERHADAP STRES KERJA PADA BAGIAN QUALITY CONTROL ASSY DI PT. XXX
}

\author{
Nandang, Asep Jamaludin, Wanta \\ Program Studi Manajemen Fakultas Ekonomi dan Bisnis Universitas Buana Perjuangan \\ Karawang \\ nandang@ubpkarawang.ac.id \\ asepjamaludin@ubpkarawang.ac.id \\ wanta@ubpkarawang.ac.id
}

\begin{abstract}
ABSTRAK
Penelitian ini bertujuan untuk memperoleh bukti-bukti empirik dan menemukan kejelasan fenomena serta kesimpulan tentang pengaruh Lingkungan Kerja dan Gaya Kepemimpinan terhadap Stres Kerja Pada Bagian Quality Control Assy di PT. XXX. Penelitian dilakukan dengan menggunakan metode deskriptif dan induktif, yaitu; mengumpulkan, menyajikan, menganalisis dan melakukan pengujian hipotesis, serta membuat kesimpulan dan saran. Dari analisis penelitian, menunjukan bahwa Lingkungan kerja secara parsial berpengaruh signifikan terhadap stres kerja, Gaya kepemimpinan secara parsial tidak berpengaruh signifikan terhadap stres kerja, Lingkungan kerja dan gaya kepemimpinan secara simultan berpengaruh signifikan terhadap stres kerja. Selanjutnya, kesinambungan penelitian diperlukan penelitian lebih lanjut mengenai variabel-variabel yang tidak terakomodasi dalam penelitian ini, yaitu variabel-variabel lain yang belum diteliti oleh peneliti, yang dapat berpengaruh terhadap stres kerja karyawan pada bagian quality control assy di PT. XXX.
\end{abstract}

Kata Kunci: Lingkungan kerja, gaya kepemimpinan dan stress kerja

\begin{abstract}
This research aims to obtain empirical evidence and find clarity of phenomena and conclusions about the influence of the Work Environment and Leadership Style on Job Stress in the Quality Control Assy Section at PT. XXX. The research was conducted using descriptive and inductive methods, namely; collect, present, analyze and test hypotheses, and make conclusions and suggestions. From the results of the analysis of research show that the work environment partially has a significant effect on work stress, partial leadership style has no significant effect on work stress, the work environment and leadership style simultaneously have a significant effect on work stress. Furthermore, the continuity of research requires further research on variables not accommodated in this study, namely other variables that have not been studied by researchers, which can affect the stress of employee work on the quality control assy at PT. XXX.
\end{abstract}

Key words: The work environment, Leadership style and work stress

\section{PENDAHULUAN}

Permintaan terhadap unit sepeda motor sangat tinggi terutama permintaan dari dalam negeri karena sepeda motor merupakan alat transportasi yang murah, praktis dan efisien sehingga menjadi pilihan masyarakat baik sebagai alat transfortasi pribadi maupun keluarga. 
Sepeda motor sudah diproduksi dan dirakit di dalam negeri, salahsatu perusahaan yang bergerak dalam perakitan sepeda motor dan memproduksi spare partnya adalah PT XXX merupakan salah satu perusahaan manufacturing asing (PMA) Jepang yang berlokasi di Karawang Jawa barat.

Tingginya permintaan produk sepeda motor di pasaran membuat PT XXX meningkatkan produksinya lebih besar lagi. Bertambahnya produksi mendorong perusahaan untuk menambah jam kerja tambahan (lembur). Tingginya jam lembur yang harus dijalankan oleh karyawan jelas berpengaruh terhadap beban kerja yang harus dijalankan oleh karyawan termasuk di bagian Quality Control Assy PT XXX. Berikut data jam lembur di bagian Quality Control Assy selama 6 (enam) bulan terakhir (JuliDesember 2018)

Tabel 1.4.

Data Jam Lembur Bulan Juli-Agustus 2018

Bagian Quality Control Assy

\begin{tabular}{|c|c|c|}
\hline \multirow[b]{2}{*}{ No } & \multicolumn{2}{|c|}{ Tahun 2018} \\
\hline & Bulan & Total Jam Lembur \\
\hline 1. & Juli & 101,5 \\
\hline 2. & Agustus & 110 \\
\hline 3. & September & 119 \\
\hline 4. & Oktober & 115 \\
\hline 5. & November & 119 \\
\hline 6. & Desember & 157 \\
\hline & Total & 721.5 \\
\hline
\end{tabular}

Karyawan menjadi pelaku yang menunjang tercapainya tujuan perusahaan. Karyawan mempunyai pikiran, perasaan dan keinginan yang dapat mempengaruhi sikapsikapnya terhadap pekerjaannya. Sikap ini akan menentukan prestasi kerja, dedikasi, dan kecintaan terhadap pekerjaan yang dibebankan kepadanya. Sikap-sikap positif harus dibina, sedangkan sikap-sikap negatif seperti stres kerja hendaknya dihindari sedini mungkin. Stres kerja dapat diakibatkan karena faktor pekerjaan maupun diluar pekerjaan. Stres kerja juga dapat menurunkan semangat kerja dan produktifitas karyawan dalam suatu perusahaan.

"Priyoto (2014:6)" menyatakan bahwa stres tahap I (satu) merupakan stres yang paling ringan yang biasanya disertai dengan perasaan-perasaan sebagai berikut:

a. Semangat bekerja besar, berlebihan (over acting)

b. Penglihatan "tajam” tidak sebagaimana biasa 
c. Merasa mampu menyelesaikan pekerjaan lebih dari biasanya, namun tanpa disadari cadangan energi dihabiskan (all out) disertai rasa gugup yang berlebihan

d. Merasa senang dengan pekerjaannya itu dan semakin bertambah semangat, namun tanpa disadari cadangan energi semakin menipis.

Handoko (2009:202) menyatakan bahwa stres kerja yang dialami oleh karyawan dapat membantu (fungsional) dalam meningkatkan kinerja karyawan, tetapi dapat juga sebaliknya, yaitu menghambat atau merusak (infungsional) kinerja karyawan.

Stres kerja dapat menimbulkan pengaruh negatif yang dapat mempengaruhi prestasi kerja karyawan. Hal ini ditegaskan dari hasil penelitian Agung Dwi Saputra (2014) bahwa stres kerja berpengaruh negative dan signifikan terhadap prestasi kerja karyawan. Hasil penelitian Aldy Pambudi Wicaksono (2017) menujukkan bahwa stres kerja memiliki pengaruh positif terhadap kinerja karyawan depot LPG balongan PT Pertamina. Stres kerja juga sangat mempengaruhi kinerja karyawan, menurut penelitian Tri Wartono (2017) menunjukkan bahwa terjadi pengaruh yang sangat kuat antara stres kerja dengan kinerja karyawan. Dan stres kerja berpengaruh positif karena semakin tinggi tingkat stres kerja semakin baik kinerja karyawan.

Gaya pemimpin dalam memimpin bawahannya mempunyai peran yang besar dalam menciptakan hubungan dengan bawahannya, salah satu hubungan tersebut adalah hubungan komunikasi dengan bawahan. Seorang pemimpin harus dapat membangun komunikasi dengan bawahan agar dapat terciptanya hubungan kerja yang baik antara pimpinan dan karyawan, dengan terciptanya hubungan kerja yang baik tersebut maka seorang pemimpin dapat meningkatkan kinerja karyawan dengan baik, menciptakan produktifitas kerja karyawan yang tinggi dan tercapainya tujuan organisasi perusahaan.

Wukir (2013: 134) menyatakan kepemimpinan merupakan seni memotivasi dan mempengaruhi sekelompok orang untuk bertindak mencapai tujuan bersama. Pada umumnya proses mempengaruhi ini dilakukan oleh seorang pemimpin terhadap bawahannya. Nawawi (2011:15) menyatakan bahwa gaya kepemimpinan adalah perilaku atau cara yang dipilih dan dipergunakan pemimpin dalam mempengaruhi pikiran, perasaan, sikap dan perilaku para anggota organisasi atau bawahannya. Seseorang yang menduduki jabatan pimpinan mempunyai kapasitas untuk membaca situasi yang dihadapinya secara tepat dan menyesuaikan gaya kepemimpinanya agar sesuai dengan tuntutan situasi yang dihadapinya, meskipun penyeseuaian ini hanya bersifat sementara. 
Gaya pemimpin mempunyai peran penting dalam perusahaan, perilaku seorang pemimpin dapat mempengaruhi tingkat stres kerja karyawan Yulinda Rachmawati (2011). Hasil penelitian Imaniar Cahya Komala (2013) menyatakan bahwa pengaruh gaya kepemimpinan terhadap stres kerja terdapat hubungan yang kuat. Sedangkan penelitian yang dilakukan oleh Erma Yulia dan Djudi Mukzam (2017) menyatakan bahwa gaya kepemimpinan otoriter berpengaruh positif terhadap stres kerja, gaya kepemimpina demokratis berpengaruh negative terhadap stres kerja dan gaya kepemimpinan laissez faire berpengaruh negative terhadap stres kerja.

Lingkungan kerja merupakan komponen penting dalam melakukan aktivitas bekerja karena lingkungan kerja yang baik dan nyaman akan membuat karyawan yang bekerja pada perusahaan dapat melakukan tugasnya dengan optimal, sedangkan jika lingkungan kerja yang tidak baik dapat menurunkan semangat kerja karyawan, menimbulkan ketidak nyamanan dalam bekerja dan menimbulkan stres kerja bagi karyawan.

Hasil pengamatan peneliti pada area kerja bagian quality control assy bahwa lingkungan kerja fisik dan non fisik pada bagian quality control assy terlihat baik, penataan tempat kerja yang tertata rapih, sarana dan prasarana yang disediakan oleh perusahaan untuk menunjang kenyamanan bekerja dan produktifitas lengkap, perlengkapan kerja yang diberikan untuk keamanan bekerja (safety) yang memadai, pemisahan area kerja, area jalan, area penempatan troly (daisha) dan area penempatan part yang baik, metode kerja yang sesuai dengan standar kerja, standar kerja yang mengacu pada standarisasi Jepang serta penerapan 5S atau 5P (Pemisahan, Penataan, Pembersihan, Perawatan dan Pembiasaan) yang diterapkan dengan baik, jelas hal ini dapat memberikan dampak yang positif dalam kenyamanan bekerja karyawan.

Lingkungan kerja merupakan tempat di mana seseorang karyawan bekerja baik sebagai perseorangan maupun sebagai kelompok. Menurut Sedarmayanti (2011:28) ada beberapa faktor yang dapat mempengaruhi terbentuknya suatu kondisi lingkungan kerja diantaranya penerangan/cahaya di tempat kerja, temperatur/suhu udara di tempat kerja, kelembaban di tempat kerja, sirkulasi udara di tempat kerja, kebisingan ditempat kerja, getaran mekanis di tempat kerja, bau tidak sedap di tempat kerja, tata warna di tempat kerja, dekorasi di tempat kerja, music di tempat kerja, dan keamanan di tempat kerja, jika ruangan kerja tidak nyaman, cahaya yang kurang, panas, sirkulasi udara kurang memadai, ruangan kerja terlalu padat, lingkungan kerja kurang bersih, berisik, tata warna 
yang kurang menarik, dekorasi yang kurang baik dan tidak aman tentu besar pengaruhnya pada kenyamanan kerja karyawan.

Perusahaan harus mampu menciptakan lingkungan kerja yang baik, lingkungan kerja yang baik akan membawa pengaruh terhadap kinerja karyawan dan menurunkan tingkat stres kerja karyawan. Hasil dari penelitian oleh Muhammad Rizki, Djamhur Hamid dan Yuniadi Mayowan (2016) menyatakan bahwa adanya hubungan antara lingkungan kerja fisik dan lingkungan kerja non fisik secara simultan berpengaruh terhadap stres kerja pada karayawan di PT. PLN (Persero) Distribusi Jawa Timur Area Pelayanan Malang sebesar 34,6\%. Hasil penelitian Yulia Febriani Rahayu (2014) menyatakan bahwa ada pengaruh yang signifikan antar variabel lingkungan kerja fisik dan variabel lingkungan kerja non fisik terhadap variabel kerja karyawan pada PJ. Muria Jaya Kudus secara parsial memberikan pengaruh negative dan signifikan terhadap stres kerja karyawan serta mempunyai kontribusi sebesar 16,9\% terhadap stres kerja. Penelitian yang dilakukan oleh Teddy Chandra dan Priyono menyatakan bahwa ada hubungan yang sangat kuat antara gaya kepemimpinan, lingkungan kerja dan kepuasan kerja terhadap kinerja dengan koefisien korelasi (R) sebesar 0,969.

\section{METODE PENELITIAN}

\section{Metode Penelitian}

Metode penelitian yang digunakan adalah descriptive survey dan explanatory yaitu survey untuk menggambarkan asosiasi, hubungan atau pengaruh variabel independen terhadap variabel dependen, sedangkan sifat penelitian adalah deskriptif dan verifikatif.

\section{Waktu dan Tempat Penelitian}

Penelitian ini dilaksanakan di perusahaan otomotif PT.XXX yang berlokasi di Karawang-Jawa Barat. Penelitian dilaksanakan selama 4 bulan dari bulan Desember 2018 sampai dengan Maret 2019.

\section{Populasi, Sampel dan Teknik Sampling}

Teknik penentuan data yang dilakukan oleh peneliti adalah dengan menggunakan teknik probability sampling, yaitu semua anggota populasi diberikan peluang yang sama untuk dipilih menjadi sampel atau pengambilan sempel secara random/acak. Dalam penelitian ini populasi diambil pada bagian Quality Control Assy sebanyak 128 karyawan. Dalam 
penentuan jumlah sampel penelitian peneliti menggunakan rumus Yamane dengan taraf kesalahan 5\% (Sugiono 2018:143). Diperoleh $\square=97$ (pembulatan). Adapun teknik sampling yang digunakan adalah simple random sampling. (Sugiono 2011:62).

Profil Sampel Penelitian

\begin{tabular}{|c|c|c|c|c|c|c|c|}
\hline \multirow{2}{*}{$\begin{array}{l}\text { Jumlah } \\
\text { Responden }\end{array}$} & \multicolumn{2}{|c|}{ Jenis Kelamin } & \multicolumn{2}{c|}{ Posisi Kerja } & \multicolumn{3}{c|}{ Pendidikan Terakhir } \\
\cline { 2 - 7 } & Laki-Laki & Perempuan & Operator & Administrasi & SMA & D3 & S1 \\
\hline 97 & 89 & 8 & 93 & 4 & 92 & 1 & 4 \\
\hline
\end{tabular}

Sumber: Hasil Olahan Kuesioner, 2019

\section{Rancangan Analisis}

Penelitian ini menggunakan skala likert dan rentang skala sebagai berikut:

Skala Likert

\begin{tabular}{|l|l|l|c|}
\hline Lingkungan Kerja & Gaya kepemimpinan & \multicolumn{1}{|c|}{ Stres Kerja } & Bobot Skor \\
\hline Sangat Setuju & Sangat Setuju & Sangat Setuju & 5 \\
\hline Setuju & Setuju & Setuju & 4 \\
\hline Cukup Setuju & Cukup Setuju & Cukup Setuju & 3 \\
\hline Tidak Setuju & Tidak Setuju & Tidak Setuju & 2 \\
\hline Sangat Tidak Setuju & Sangat Tidak Setuju & Sangat Tidak Setuju & 1 \\
\hline
\end{tabular}

Sumber: Sugiyono, 2011

Analisis Rentang Skala

\begin{tabular}{|c|c|c|c|c|}
\hline \multirow{2}{*}{ Skala Skor } & Rentang Skala & Deskripsi Skor & \multicolumn{3}{|c|}{ Stres Kerja } \\
\cline { 3 - 5 } & $97-174,6$ & Sangat Tidak Setuju & $\begin{array}{c}\text { Gaya } \\
\text { Sepemimpinan } \\
\text { Setuju }\end{array}$ & Sangat Tidak Setuju \\
\hline 1 & $174,7-252,2$ & Kurang Setuju & Kurang Setuju & Kurang Setuju \\
\hline 2 & $252,3-329,8$ & Cukup Setuju & Cukup Setuju & Cukup Setuju \\
\hline 3 & $329,9-407,4$ & Setuju & Setuju & Setuju \\
\hline 4 & $407,5-485$ & Sangat Setuju & Sangat Setuju & Sangat Setuju \\
\hline 5 & &
\end{tabular}

Sumber: Sugiono, 2011 (disesuaikan) 


\section{Uji Hipotesis}

Uji hipotesis yang digunakan dalam penelitian ini:

1. Uji Klasik

2. Uji Korelasi

3. Uji Koefisien Determinasi $\left(\mathrm{R}^{2}\right)$

4. Analisis Jalur (Path Analysis)

5. Pengujian Hipotesis Secara Parsial (Uji t)

6. Pengujian Hipotesis Secara Simultan (Uji F)

7. Analisis Pengujian Hipotesis

Pengujian hipotesis dalam penelitian ini adalah uji pihak kanan berarti "adanya pengaruh variabel dependen (bebas) terhadap independen (terikat)" dan uji pihak kiri "tidak adanya pengaruh variabel dependen (bebas) terhadap independen (terikat)"

Hipotesis I

- $\mathrm{H}_{0} 1: \rho=0 \quad$ Lingkungan kerja tidak memiliki pengaruh terhadap stres kerja pada bagian quality control assy di PT. XXX.

- $\mathrm{H}_{\mathrm{a}} 1: \rho \neq 0 \quad$ Lingkungan kerja memiliki pengaruh terhadap stres kerja karyawan pada bagian quality control assy di PT. XXX.

Kriteria $\quad \mathrm{H}_{\mathrm{o}}$ ditolak jika $\mathrm{t}_{\text {hitung }}>\mathrm{t}$ tabel

Hipotesis II

- $\mathrm{H}_{0} 2: \rho=0 \quad$ Kepemimpinan tidak memiliki pengaruh terhadap stres kerja pada bagian Quality Control Assy di PT. XXX.

- $\mathrm{H}_{\mathrm{a}} 2: \rho \neq 0 \quad$ Kepemimpinan memiliki pengaruh terhadap stres kerja pada bagian Quality Control Assy di PT. XXX.

Kriteria $\quad \mathrm{H}_{\mathrm{o}}$ ditolak jika $\mathrm{t}_{\text {hitung }}>\mathrm{t}$ tabel

Hipotesis III

- $\mathrm{H}_{0} 3: \rho=0$ Lingkungan kerja dan kepemimpinan tidak memiliki pengaruh dengan stres kerja pada bagian Quality Control Assy di PT. XXX.

- $\mathrm{H}_{\mathrm{a}} 3: \rho \neq 0 \quad$ Lingkungan kerja dan kepemimpinan memiliki pengaruh dengan Stres Kerja pada bagian Quality Control Assy di PT. XXX.

Kriteria $\quad \mathrm{H}_{\mathrm{o}}$ ditolak jika $\mathrm{F}_{\text {hitung }}>\mathrm{F}_{\text {tabel }}$ 


\section{HASIL PENELITIAN DAN PEMBAHASAN}

\section{Hasil Penelitian}

Berdasarkan perhitungan menggunakan SPSS diperoleh hasil sebagai berikut:

\section{Uji Validitas Lingkungan Kerja $\left(\mathbf{X}_{1}\right)$}

\begin{tabular}{|c|c|c|c|c|}
\hline \multicolumn{5}{|c|}{ Item-Total Statistics } \\
\hline & $\begin{array}{l}\text { Scale Mean if } \\
\text { Item Deleted }\end{array}$ & $\begin{array}{l}\text { Scale Variance if } \\
\text { Item Deleted }\end{array}$ & $\begin{array}{l}\text { Corrected Item- } \\
\text { Total Correlation }\end{array}$ & $\begin{array}{l}\text { Cronbach's } \\
\text { Alpha if Item } \\
\text { Deleted }\end{array}$ \\
\hline pert_1 & 54.8351 & 52.952 & .562 & .932 \\
\hline pert_2 & 54.8557 & 53.208 & .579 & .931 \\
\hline pert_3 & 55.0412 & 53.498 & .596 & .931 \\
\hline pert_4 & 54.8041 & 52.055 & .631 & .930 \\
\hline pert_5 & 54.9175 & 52.410 & .679 & .929 \\
\hline pert_6 & 55.2784 & 50.036 & .737 & .927 \\
\hline pert_7 & 55.2990 & 50.962 & .732 & .927 \\
\hline pert_8 & 55.2165 & 49.359 & .801 & .925 \\
\hline pert_9 & 55.3711 & 50.111 & .665 & .929 \\
\hline pert_10 & 55.2680 & 50.990 & .691 & .928 \\
\hline pert_11 & 55.4227 & 51.267 & .544 & .934 \\
\hline pert_12 & 55.0928 & 51.439 & .602 & .931 \\
\hline pert_13 & 55.0412 & 50.498 & .747 & .927 \\
\hline pert_14 & 54.9691 & 50.884 & .735 & .927 \\
\hline pert_15 & 55.0206 & 49.583 & .808 & .925 \\
\hline
\end{tabular}

Sumber: Data Olahan SPSS Versi 16.0 (2019)

\section{Uji Validitas Gaya Kepemimpinan $\left(\mathbf{X}_{2}\right)$}

\begin{tabular}{|l|r|r|r|r|}
\hline & $\begin{array}{c}\text { Item-Total Statistics } \\
\text { Scale Mean if } \\
\text { Item Deleted }\end{array}$ & $\begin{array}{c}\text { Scale Variance if } \\
\text { Item Deleted }\end{array}$ & $\begin{array}{c}\text { Cronbach's } \\
\text { Corrected Item- } \\
\text { Total Correlation }\end{array}$ & $\begin{array}{c}\text { Alpha if Item } \\
\text { Deleted }\end{array}$ \\
\hline pert_1 & 42.1913 & 50.928 & .654 & .853 \\
pert_2 & 41.8261 & 49.268 & .630 & .855 \\
pert_3 & 42.6087 & 51.030 & .667 & .853 \\
pert_4 & 42.6522 & 52.369 & .593 & .857 \\
pert_5 & 42.6696 & 52.557 & .670 & .854 \\
pert_6 & 40.8174 & 57.256 & .279 & .871
\end{tabular}


Item-Total Statistics

\begin{tabular}{|l|r|r|r|r|}
\hline & $\begin{array}{c}\text { Scale Mean if } \\
\text { Item Deleted }\end{array}$ & $\begin{array}{c}\text { Scale Variance if } \\
\text { Item Deleted }\end{array}$ & $\begin{array}{c}\text { Cronbach's } \\
\text { Corrected Item- } \\
\text { Total Correlation }\end{array}$ & $\begin{array}{c}\text { Al Item } \\
\text { Deleted }\end{array}$ \\
\hline pert_7 & 40.6609 & 57.103 & .312 & .870 \\
pert_8 & 41.0087 & 55.623 & .450 & .864 \\
pert_9 & 40.7478 & 55.260 & .470 & .863 \\
pert_10 & 40.6957 & 55.670 & .431 & .865 \\
pert_11 & 42.0696 & 56.048 & .268 & .875 \\
pert_12 & 42.2957 & 51.719 & .633 & .855 \\
pert_13 & 42.5826 & 57.070 & .367 & .867 \\
pert_14 & 42.6261 & 52.113 & .639 & .855 \\
pert_15 & 42.6000 & 52.330 & .649 & .855 \\
\hline
\end{tabular}

Sumber: Data Olahan SPSS Versi 16.0 (2019)

\section{Uji Validitas Stres Kerja (Y)}

\begin{tabular}{|c|c|c|c|c|}
\hline \multicolumn{5}{|c|}{ Item-Total Statistics } \\
\hline & $\begin{array}{l}\text { Scale Mean if } \\
\text { Item Deleted }\end{array}$ & $\begin{array}{c}\text { Scale Variance if } \\
\text { Item Deleted }\end{array}$ & $\begin{array}{l}\text { Corrected Item- } \\
\text { Total Correlation }\end{array}$ & $\begin{array}{c}\text { Cronbach's } \\
\text { Alpha if Item } \\
\text { Deleted }\end{array}$ \\
\hline VAR00001 & 24.8866 & 32.539 & .600 & .899 \\
\hline VAR00002 & 25.0206 & 31.645 & .491 & .904 \\
\hline VAR00003 & 25.0206 & 31.583 & .659 & .897 \\
\hline VAR00004 & 24.9691 & 32.093 & .626 & .898 \\
\hline VAR00005 & 24.8247 & 33.438 & .451 & .904 \\
\hline VAR00006 & 25.2268 & 31.344 & .720 & .895 \\
\hline VAR00007 & 25.1443 & 31.146 & .681 & .896 \\
\hline VAR00008 & 25.3814 & 32.697 & .454 & .904 \\
\hline VAR00009 & 25.5155 & 32.273 & .600 & .899 \\
\hline VAR00010 & 25.3093 & 31.570 & .595 & .895 \\
\hline VAR00011 & 25.4124 & 31.557 & .663 & .897 \\
\hline VAR00012 & 25.1856 & 30.778 & .586 & .900 \\
\hline VAR00013 & 25.0928 & 31.398 & .698 & .896 \\
\hline VAR00014 & 24.9588 & 32.457 & .498 & .903 \\
\hline VAR00015 & 25.0412 & 31.790 & .654 & .897 \\
\hline
\end{tabular}

Sumb: Sumber; Data Olahan SPSS Versi 16.0 (2019) 
Berdasrkan hasil uji validitas Lingkungan Kerja $\left(\mathrm{X}_{1}\right)$ mulai dari $\mathrm{X}_{1}-1$ s.d $\mathrm{X} 1$-1, gaya kepemimpinan $\left(\mathrm{X}_{2}\right)$ mulai dari butir $\mathrm{X}_{2}-1$ s.d $\mathrm{X}_{2}-15$ serta stress kerja (Y) mulai dari $\mathrm{Y}$ 1 s.d Y-15 diperoleh nilai Corrected Item-Total Correlation lebih besar dari nilai $\mathrm{r}$ tabel dengan menggunakan $\mathrm{df}=\mathrm{n}-3=97-3=94$. Pada tingkat signifikasi sebesar 5\%, didapat angka $\mathrm{r}$ tabel $=0,203$. Hal tersebut menunjukan bahwa pertanyaan-pertanyaan yang terdapat pada variabel Lingkungan Kerja $\left(\mathrm{X}_{1}\right)$, gaya kepemimpinan $\left(\mathrm{X}_{2}\right)$ dan stres kerja $(\mathrm{Y})$ dinyatakan valid dan bisa digunakan untuk penelitian selanjutnya.

Uji Reliabilitas Lingkungan Kerja $\left(\mathbf{X}_{1}\right)$

Reliability Statistics

\begin{tabular}{|r|r|}
\hline Cronbach's Alpha & \multicolumn{2}{|l|}{ N of Items } \\
\hline .933 & 15 \\
\hline
\end{tabular}

Uji Reliabilitas Gaya Kepemimpinan $\left(\mathbf{X}_{2}\right)$

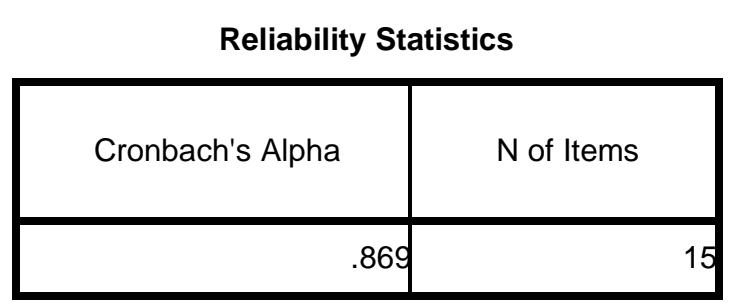

\section{Uji Reliabilitas Stres Kerja (Y)}

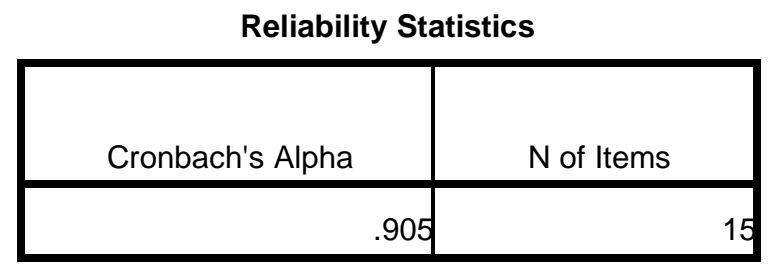

Hasil SPSS Versi 16.0 uji reliabilitas Lingkungan Kerja $\left(\mathrm{X}_{1}\right)$ Uji Reliabilitas Gaya Kepemimpinan (X2) dan stress kerja (Y) semuanya lebih besar dari 0,6 maka data kuesioner tersebut dinyatakan reliabel dan dapat digunakan sebagai instrumen penelitian selanjutnya. 


\section{Uji Normalitas}

One-Sample Kolmogorov-Smirnov Test

\begin{tabular}{|ll|r|r|r|}
\hline & & Lingkungan_kerja & Gaya_kepemimpinan & Stres_kerja \\
\hline N & & 97 & 97 & 97 \\
Normal Parameters ${ }^{2}$ & Mean & 59.0309 & 44.5567 & 26.9278 \\
& Std. Deviation & 7.65459 & 7.90302 & 6.02987 \\
Most Extreme Differences & Absolute & .107 & .127 & .105 \\
& Positive & .068 & .127 & .105 \\
& Negative & -.107 & -.090 & -.088 \\
Kolmogorov-Smirnov Z & & 1.055 & 1.252 & 1.038 \\
Asymp. Sig. (2-tailed) & & .216 & .087 & .231 \\
\hline
\end{tabular}

a. Test distribution is Normal.

Sumber: Data Olahan SPSS Versi 16.0

Hasil SPSS uji normalitas diketahui bahwa nilai Asymp. Sig. (2-tailed) lingkungan kerja sebesar 0,216, gaya kepemimpinan sebesar 0,087 dan stres kerja sebesar 0,231 lebih besar dari nilai alpha 0,05 sehingga data kuesioner dinyatakan terdistribusi normal.

\section{Pembahasan}

Berdasarkan hasil rekapitulasi variabel lingkungan kerja $\left(\mathrm{X}_{1}\right)$ dapat diketahui bahwa variabel lingkungan kerja terdiri dari 15 pernyataan dengan total skor yaitu 5726 dan rata-rata skor yaitu 381,7 (Setuju = 329,9 - 407,4). Rata-rata skor yaitu 381,7 berada pada "setuju", ini berarti variabel lingkungan kerja sudah baik terlaksana namun masih belum maksimal karena belum mencapai daerah sangat setuju/baik, bahkan dari 15 indikator di atas seluruhnya berada pada kriteria setuju/baik.

Hasil rekapitulasi variabel gaya kepemimpinan $\left(\mathrm{X}_{2}\right)$ dapat disimpulkan bahwa variabel gaya kepemimpinan terdiri dari 15 pernyataan dengan total skor yaitu 4322 dan ratarata skor yaitu 288,1 (cukup setuju = 252,3 - 329,8). Rata-rata skor yaitu 288,1 berada pada "cukup setuju", ini berarti variabel gaya kepemimpinan sudah cukup baik terlaksana namun masih belum maksimal karena belum mencapai daerah sangat setuju/baik.

Hasil rekapitulasi variabel stres kerja (Y) dapat disimpulkan bahwa variabel stres kerja terdiri dari 15 pernyataan dengan total skor yaitu 5627 dan rata-rata skor yaitu 161,7 (Sangat Tidak Setuju = $97-174,6$ ). Rata-rata skor yaitu 161,7 yang berada pada "sangat tidak setuju", ini berarti tingkat stres kerja sangat rendah. 


\section{Uji Korelasi}

\begin{tabular}{|ll|r|r|r|}
\hline & & \multicolumn{2}{c|}{ Correlations } \\
& & Stres_kerja & Lingkungan_kerj & Gaya_kepemimp \\
& anar & ina \\
\hline Pearson Correlation & Stres_kerja & 1.000 & -.567 & -.336 \\
& Lingkungan_kerja & -.567 & 1.000 & .387 \\
& Gaya_kepemimpinan & -.336 & .382 & 1.000 \\
\hline Sig. (1-tailed) & Stres_kerja & & .000 & .000 \\
& Lingkungan_kerja & .000 & & .000 \\
& Gaya_kepemimpinan & .000 & .000 & 97 \\
\hline $\mathrm{N}$ & Stres_kerja & 97 & 97 & 97 \\
& Lingkungan_kerja & 97 & 97 & 97 \\
& Gaya_kepemimpinan & 97 & 97 & 97 \\
\end{tabular}

Sumber: Data Olahan SPSS Versi 16.0 (2019)

Berdasarkan Tabel hasil SPSS uji korelasi antara lingkungan kerja $\left(\mathrm{X}_{1}\right)$ dan gaya kepemimpinan $\left(\mathrm{X}_{2}\right)$ diatas nilai koefisien korelasinya sebesar 0,382 artinya angka tersebut menunjukan bahwa terdapat hubungan yang linier positif dan signifikan antara lingkungan kerja dengan gaya kepemimpinan,

\section{Uji Koefisien Determinasi $\left(\mathbf{R}^{2}\right)$}

\section{Model Summary}

\begin{tabular}{|c|c|c|c|c|c|c|c|c|c|}
\hline \multirow[b]{2}{*}{ Mode } & \multirow[b]{2}{*}{$\mathrm{R}$} & \multirow[b]{2}{*}{$\begin{array}{c}\mathrm{R} \\
\text { Square }\end{array}$} & \multirow[b]{2}{*}{$\begin{array}{c}\text { Adjusted R } \\
\text { Square }\end{array}$} & \multirow{2}{*}{$\begin{array}{c}\text { Std. Error of } \\
\text { the } \\
\text { Estimate }\end{array}$} & \multicolumn{5}{|c|}{ Change Statistics } \\
\hline & & & & & $\begin{array}{c}\text { R Square } \\
\text { Change }\end{array}$ & $\begin{array}{c}F \\
\text { Change }\end{array}$ & df1 & df2 & $\begin{array}{l}\text { Sig. F } \\
\text { Change }\end{array}$ \\
\hline 1 & $.582^{a}$ & .338 & .324 & 4.95656 & .338 & 24.039 & 2 & 94 & .000 \\
\hline
\end{tabular}

a. Predictors: (Constant), Gaya_kepemimpinan,Lingkungan_kerja

Sumber: Data Olahan SPSS Versi 16.0 (2019)

Berdasarkan hasil uji koefisien determinasi secara simultan antara lingkungan kerja dan gaya kepemimpinan terhadap stres kerja didapatkan nilai sebesar 33,8\%. Artinya bahwa secara simultan lingkungan kerja dan gaya kepemimpinan mempengaruhi stres kerja sebesar $33,8 \%$, sedangkan sisanya sebesar $66,2 \%$ dipengaruhi oleh faktor-faktor lain yang tidak diteliti. 


\section{Analisis Jalur (Path Analysis)}

Coefficients $^{a}$

\begin{tabular}{|c|c|c|c|c|c|c|c|c|}
\hline \multirow{2}{*}{\multicolumn{2}{|c|}{ Model }} & \multicolumn{2}{|c|}{$\begin{array}{c}\text { Unstandardized } \\
\text { Coefficients }\end{array}$} & \multirow{2}{*}{$\begin{array}{c}\begin{array}{c}\text { Standardized } \\
\text { Coefficients }\end{array} \\
\text { Beta }\end{array}$} & \multirow[b]{2}{*}{$t$} & \multirow[b]{2}{*}{ Sig. } & \multicolumn{2}{|c|}{$\begin{array}{c}95 \% \text { Confidence Interval } \\
\text { for B }\end{array}$} \\
\hline & & B & Std. Error & & & & $\begin{array}{l}\text { Lower } \\
\text { Bound }\end{array}$ & $\begin{array}{l}\text { Upper } \\
\text { Bound }\end{array}$ \\
\hline \multirow[t]{3}{*}{1} & (Constant) & 55.577 & 4.201 & & 13.229 & .000 & 47.236 & 63.918 \\
\hline & Lingkungan_kerja & -.405 & .071 & -.514 & -5.658 & .000 & -.547 & -.263 \\
\hline & $\begin{array}{l}\text { Gaya_kepemimpi } \\
\text { nan }\end{array}$ & -.107 & .069 & -.140 & -1.545 & .126 & -.244 & .031 \\
\hline
\end{tabular}

a. Dependent Variable: Stres_kerja

Sumber: Data Olahan SPSS Versi 16.0 (2019)

Tabel diatas menggambarkan hasil perhitungan jalur, bahwa variabel lingkungan kerja $\left(\mathrm{X}_{1)}\right.$ mempunyai koefisien jalur sebesar -0.514. Variabel gaya kepemimpinan $\left(\mathrm{X}_{2}\right)$ mempunyai koefisien jalur sebesar -140. Berdasarkan data koefisien jalur diatas maka dapat dituangkan dalam gambar analisis jalur (path analysis) sebagai berikut:

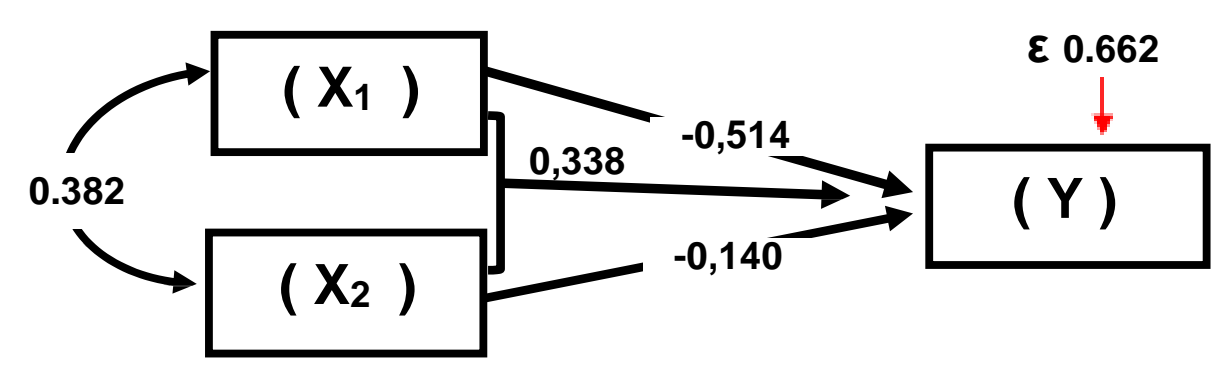

Berdasarkan gambar diatas diperoleh persamaan jalur sebagai berikut:

$$
\begin{aligned}
& Y=\rho y x_{1} X_{1}+\rho y x_{2} X_{2}+\rho \gamma C \\
& Y=-0.514 X_{1}+-0.140 X_{2}+0,662
\end{aligned}
$$

Dimana :

$\mathrm{Y}=$ Stres Kerja

$\mathrm{X}_{1}=$ Lingkungan Kerja

$\mathrm{X}_{2}=$ Gaya Kepemimpinan

$\epsilon=$ Pengaruh Faktor Lain 
Besarnya pengaruh dari masing-masing variabel bebas terhadap variabel terikat baik pengaruh langsung (Direct Effect) maupun pengaruh tidak langsung (Indirect Effect) dapat dilihat pada tabel berikut ini :

Pengaruh Langsung dan Pengaruh tidak Langsung Variabel Bebas Terhadap Variabel Terikat

\begin{tabular}{|c|c|c|c|c|}
\hline \multirow{2}{*}{ Variabel } & \multirow{2}{*}{$\begin{array}{l}\text { Pengaruh } \\
\text { Langsung }\end{array}$} & \multicolumn{2}{|c|}{ Pengaruh tidak Langsung } & \multirow{2}{*}{$\begin{array}{c}\text { Total } \\
\text { Pengaruh }\end{array}$} \\
\hline & & $\mathbf{X}_{1}$ & $\mathbf{X}_{2}$ & \\
\hline Lingkungan Kerja & $\begin{array}{l}-0,514 \times-0,514= \\
\mathbf{0 , 2 6 4 2}\end{array}$ & & $\begin{array}{l}-0,514 \times-0,140 \times \\
0,382=\mathbf{0 , 0 2 7 4}\end{array}$ & 0,2916 \\
\hline $\begin{array}{l}\text { Gaya } \\
\text { Kepemimpinan }\end{array}$ & $\begin{array}{l}-0,140 \times-0,140= \\
\mathbf{0 , 0 1 9 6}\end{array}$ & $\begin{array}{l}0,514 \times 0,146 \times \\
0,382=\mathbf{0 , 0 2 7 4}\end{array}$ & & 0,0470 \\
\hline \multicolumn{4}{|c|}{ Total Pengaruh $X_{1}$ dan $X_{1}$ terhadap $Y$} & $\begin{array}{l}0,2916 \quad+ \\
0,0470=\mathbf{0 , 3 3 8}\end{array}$ \\
\hline \multicolumn{4}{|l|}{ E } & $\begin{array}{l}100 \%-34,3 \% \\
=\mathbf{6 6 , 2} \%\end{array}$ \\
\hline
\end{tabular}

Sumber: Data Hasil Perhitungan, 2019

Berdasarkan tabel diatas, terlihat bahwa variabel lingkungan kerja $\left(\mathrm{X}_{1}\right)$ mempunyai pengaruh langsung adalah 0,2642 atau sebesar 26,42\%, pengaruh tidak langsung melalui hubungannya dengan gaya kepemimpinan $\left(\mathrm{X}_{2}\right)$ adalah 0,0274 atau sebesar 2,74\%, sehingga total pengaruhnya langsung dan tidak langsungnya adalah 0,2916 atau sebesar 29,16\%.

Variabel gaya kepemimpinan $\left(\mathrm{X}_{2}\right)$ mempunyai pengaruh langsung adalah 0,0196 atau sebesar $1,96 \%$, pengaruh tidak langsung melalui hubungannya dengan lingkungan kerja $\left(\mathrm{X}_{1}\right)$ adalah 0,0274 atau sebesar 2,74\%, sehingga total pengaruhnya langsung dan tidak langsungnya adalah 0,338 atau sebesar $33,8 \%$.

Hasil perhitungan koefisien determinasi $\left(\mathrm{R}^{2}\right)$ yang dinyatakan dalam persentase menggambarkan besarnya kontribusi semua variabel bebas yaitu lingkungan kerja $\left(\mathrm{X}_{1}\right)$ dan gaya kepemimpinan $\left(\mathrm{X}_{2}\right)$ menentukan stres kerja $(\mathrm{Y})$ adalah 0,343 atau sebesar $34,3 \%$ dan pengaruh karena faktor lain sebesar 0,662 atau sebesar $66,2 \%$. 


\section{Pengujian Hipotesis Secara Parsial (Uji t)}

\begin{tabular}{|c|c|c|c|c|c|c|c|}
\hline \multirow[b]{2}{*}{ Model } & \multicolumn{2}{|c|}{$\begin{array}{l}\text { Unstandardized } \\
\text { Coefficients }\end{array}$} & \multirow{2}{*}{\begin{tabular}{|l}
$\begin{array}{l}\text { Standardize } \\
\text { d } \\
\text { Coefficients }\end{array}$ \\
Beta
\end{tabular}} & \multirow[b]{2}{*}{$\mathrm{t}$} & \multirow[b]{2}{*}{ Sig. } & \multicolumn{2}{|c|}{$\begin{array}{l}95 \% \quad \text { Confidence } \\
\text { Interval for B }\end{array}$} \\
\hline & B & Std. Error & & & & $\begin{array}{l}\text { Lower } \\
\text { Bound }\end{array}$ & $\begin{array}{l}\text { Upper } \\
\text { Bound }\end{array}$ \\
\hline $1 \quad$ (Constant) & 55.577 & 4.201 & & 13.229 & .000 & 47.236 & 63.918 \\
\hline Lingkungan_kerja & -.405 & .071 & -.514 & -5.658 & .000 & -.547 & -.263 \\
\hline Gaya_kepemimpinan & -.107 & .069 & -.140 & -1.545 & .126 & -.244 & $\mid .031$ \\
\hline
\end{tabular}

a. Dependent Variable: Stres_kerja

Sumber: Data Olahan SPSS Versi 16.0 (2019)

\section{Pengujian Hipotesis Secara Parsial (Uji t) Lingkungan Kerja Terhadap Stres Kerja}

Hasil SPSS uji secara parsial (uji t) lingkungan kerja terhadap stres kerja di atas diperoleh nilai $t_{\text {hitung }}$ sebesar $-5,658$ dengan signifikasi 0,000 . Nilai $t_{\text {tabel }}$ dengan menggunakan $\mathrm{df}=\mathrm{n}-\mathrm{k}=97-3=94$. Pada tingkat signifikasi sebesar $5 \%$, didapat angka $\mathrm{t}_{\text {tabel }}=1,661$, dari data tersebut diketahui $t_{\text {hitung }}>\mathrm{t}_{\text {tabe }} \mathrm{l}$ atau $-5,658>1,661$ dan nilai signifikasi $<0,05$. Hal ini berarti terdapat adanya pengaruh yang signifikan lingkungan kerja terhadap stres kerja, nilai negatif menunjukan bahwa $\mathrm{X}_{1}$ mempunyai hubungan yang berlawanan arah dengan $\mathrm{Y}$.

\section{Pengujian Hipotesis Secara Parsial (Uji t) Gaya Kepemimpinan Terhadap Stres Kerja}

Berdasarkan tabel hasil SPSS uji secara parsial (uji t) gaya kepemimpinan terhadap stres kerja di atas diperoleh nilai $t_{\text {hitung }}$ sebesar -1,545 dengan signifikasi 0,126. Nilai $t_{\text {tabel }}$ dengan menggunakan $\mathrm{df}=\mathrm{n}-\mathrm{k}=97-3=94$. Pada tingkat signifikasi sebesar 5\%, didapat angka $\mathrm{t}_{\text {tabel }}=1,661$, dari data tersebut diketahui $\mathrm{t}_{\text {hitung }}<\mathrm{t}_{\text {tabel }} \mathrm{l}$ atau $-1,545<1,661$ dan nilai signifikasi $>0,05$. Hal ini berarti tidak adanya pengaruh yang signifikan gaya kepemimpinan terhadap stres kerja, nilai negatif menunjukan bahwa $\mathrm{X}_{2}$ mempunyai hubungan yang berlawanan arah dengan Y. 


\section{Pengujian Hipotesis Secara Simultan (Uji F atau Uji Anova)}

\begin{tabular}{|c|c|c|c|c|c|c|}
\hline \multicolumn{7}{|c|}{ ANOVA $^{b}$} \\
\hline & & Sum of Squares & df & Mean Square & $\mathrm{F}$ & Sig. \\
\hline \multirow[t]{3}{*}{1} & Regression & 1181.148 & 2 & 590.574 & 24.039 & $.000^{a}$ \\
\hline & Residual & $2309.34 t$ & 94 & 24.568 & & \\
\hline & Total & 3490.495 & 96 & & & \\
\hline
\end{tabular}

a. Predictors: (Constant), Gaya_kepemimpinan, Lingkungan_kerja

b. Dependent Variable: Stres_kerja

Sumber: Data Olahan SPSS Versi 16.0 (2019)

Berdasarkan data tabel diatas, hasil SPSS uji secara simultan lingkungan kerja dan gaya kepemimpinan terhadap stres kerja di atas diperoleh nilai $F_{\text {hitung }}$ sebesar 24,039 dengan signifikasi 0,000. Nilai $F_{\text {tabel }}$ dengan menggunakan $\mathrm{df}=\mathrm{n}-\mathrm{k}=97-3=94$. Pada tingkat signifikasi sebesar 5\%, didapat angka $\mathrm{F}_{\text {tabel }}=3,09$, dari data tersebut diketahui $\mathrm{F}_{\text {hitung }}>\mathrm{F}_{\text {tabel }}$ atau 24,039 > 3,0 dan nilai signifikasinya $0,000<0,05$. Hal ini berarti terdapat ada pengaruh yang signifikan lingkungan kerja dan gaya kepemimpinan terhadap stres kerja pada bagian quality control assy di PT. XXX.

\section{Uji Pihak Kanan Lingkungan Kerja Terhadap Stres Kerja Secara Parsial}

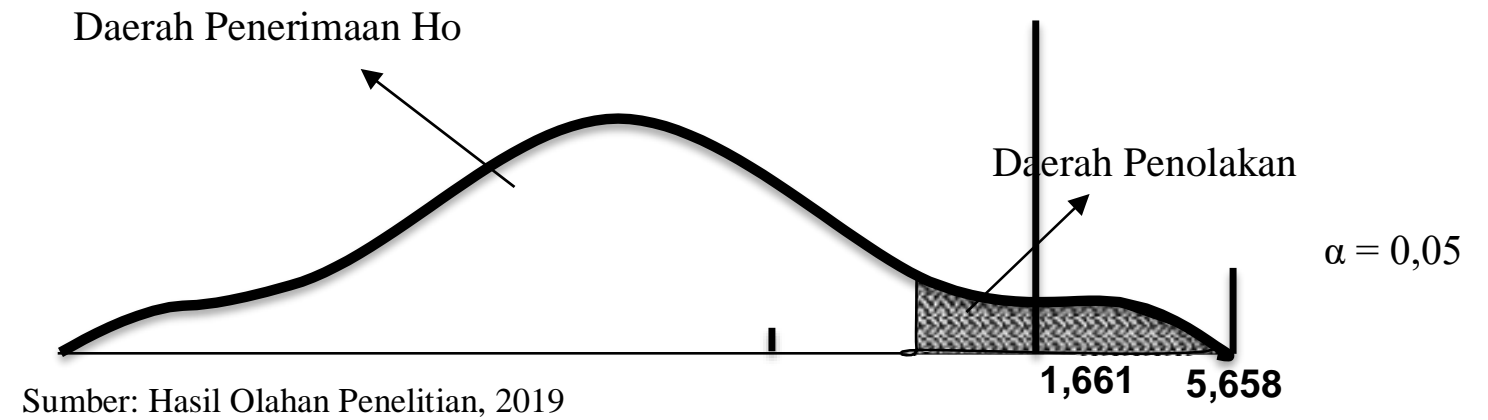

Berdasarkan gambar kurva pengujian pihak kanan lingkungan kerja terhadap stres kerja diketahui bahwa hipotesis nol ditolak dan hipotesis alternatif diterima yang berarti bahwa ada pengaruh antara lingkungan kerja terhadap stres kerja pada bagian quality control assy di PT. XXX.

Uji Pihak Kiri Gaya Kepemimpinan Terhadap Stres Kerja Secara Parsial 


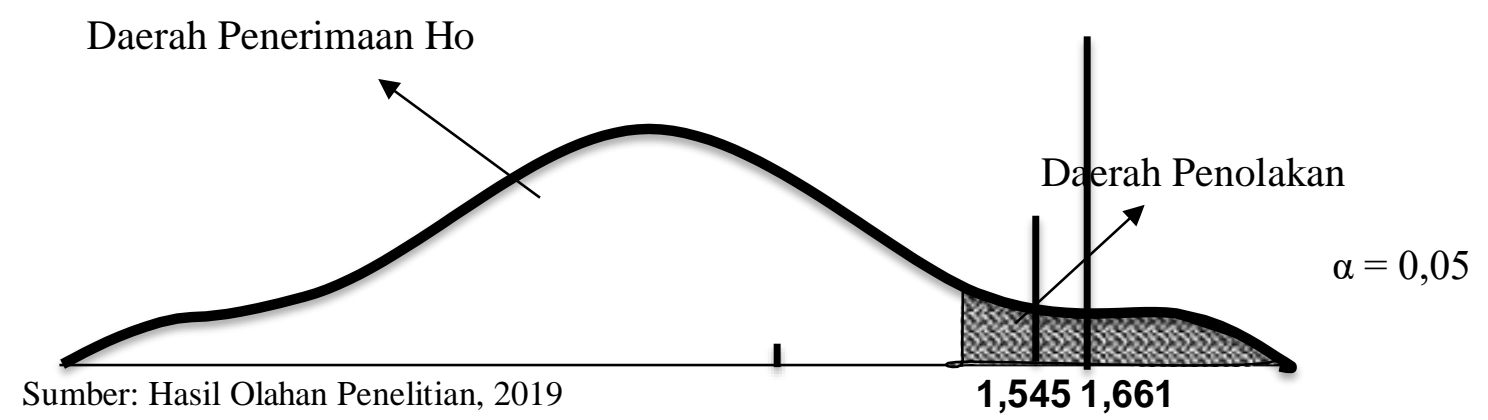

Berdasarkan gambar kurva pengujian pihak kiri gaya kepemimpinan terhadap stres kerja diketahui bahwa hipotesis nol diterima dan hipotesis alternatif ditolak yang berarti bahwa tidak ada pengaruh antara gaya kepemimpinan terhadap stres kerja pada bagian quality control assy di PT. XXX.

\section{Uji Pihak Kanan Lingkungan Kerja dan Gaya Kepemimpinan Terhadap Stres Kerja Secara Simultan}

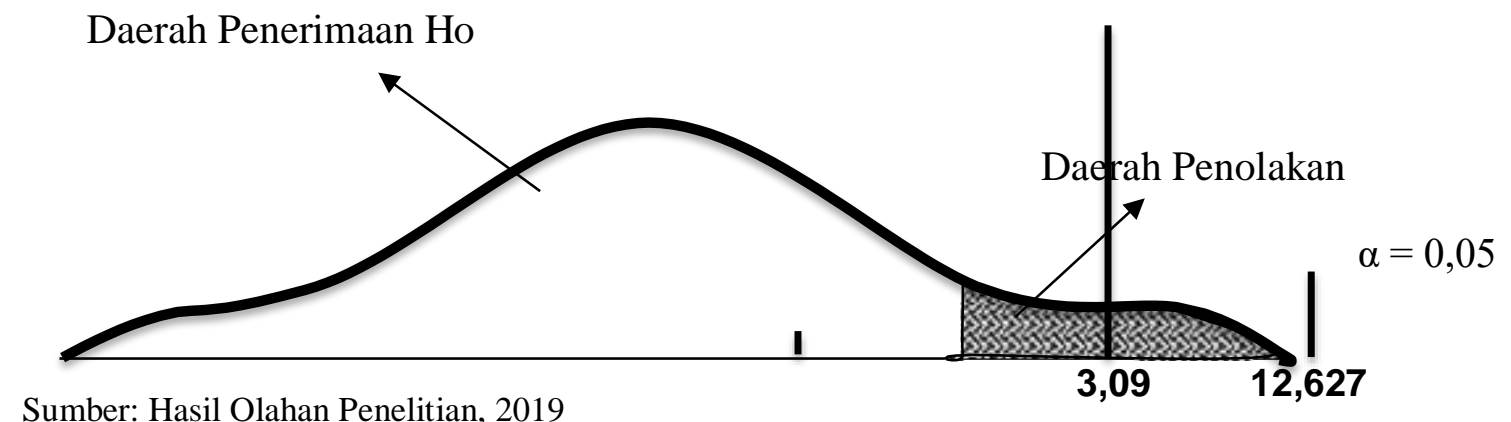

Berdasarkan gambar kurva pengujian pihak kanan lingkungan kerja dan gaya kepemimpinan terhadap stres kerja diketahui bahwa hipotesis nol ditolak dan hipotesis alternatif diterima yang berarti bahwa ada pengaruh lingkungan kerja dan gaya kepemimpinan secara bersama-sama terhadap stres kerja pada bagian quality control assy di PT. XXX. 


\section{KESIMPULAN}

1. Lingkungan kerja secara parsial berpengaruh signifikan terhadap terhadap stres kerja pada bagian quality control assy di PT. XXX. Keadaan ini ditunjukan dari nilai $t_{\text {hitung }}>t_{\text {tabel }}$ atau $.5,658>1,661$ dengan nilai signifikasi $0,000<$ nilai alpha $(\alpha) 0,05$, nilai negatif menunjukan bahwa $\mathrm{X}_{1}$ mempunyai hubungan yang berlawanan arah dengan $\mathrm{Y}$.

2. Gaya kepemimpinan secara parsial tidak berpengaruh signifikan terhadap terhadap stres kerja pada bagian quality control assy di PT. XXX. Keadaan ini ditunjukan dari nilai thitung

$>t_{\text {tabel }}$ atau $-1,545<1,661$ dengan nilai signifikasi $0,126>$ nilai alpha $(\alpha) 0,05$, nilai negatif menunjukan bahwa $\mathrm{X}_{2}$ mempunyai hubungan yang berlawanan arah dengan $\mathrm{Y}$.

3. Lingkungan kerja dan gaya kepemimpinan secara simultan berpengaruh signifikan terhadap stres kerja pada bagian quality control assy di PT. XXX. Keadaan ini ditunjukan dari nilai $F_{\text {hitung }}>F_{\text {tabel }}$ atau 24,039 $>3,09$, dengan nilai signifikasi $0,000<$ nilai $(\alpha) 0,05$.

\section{Saran Bagi Perusahaan}

1. Lingkungan kerja PT. XXX pada bagian quality control assy sudah baik namun perlu ditingkatkan lagi karena belum mencapai kondisi sangat baik, mengingat lingkungan kerja berpengaruh secara signifikan terhadap stres kerja karyawan.

2. Gaya kepemimpian pada bagian quality control assy di PT. XXX sudah cukup baik namun perlu ditingkatkan lagi menjadi baik atau sangat baik walaupun gaya kepemimpinan di bagian quality control assy tidak berpengaruh signifikan terhadap stres kerja karyawan.

3. Tingkat stres kerja karyawan pada bagian quality sangat rendah, sehingga perusahaan harus mampu mempertahankan kondisi lingkungan kerja dan gaya kepemimpinan yang saat ini ada di PT. XXX khususnya bagian quality control assy.

4. Mengingat pengaruh faktor lain terhadap stres kerja karyawan sebesar 66,2\% maka disarankan perusahaan perlu menganalisis faktor lainnya yang dapat mempengaruhi stres kerja karyawan khususnya di bagian quality control assy sehingga tujuan perusahaan dapat tercapai.

\section{Saran Bagi Peneliti Berikutnya}

Diperlukan penelitian lebih lanjut mengenai variabel-variabel yang tidak terakomodasi dalam penelitian ini, yaitu variabel-variabel lain yang belum diteliti oleh peneliti, yang dapat berpengaruh terhadap stres kerja karyawan pada bagian quality control assy di PT. XXX. 


\section{DAFTAR PUSTAKA}

Wukir. 2013. Manajemen Sumber Daya Manusia Dalam Organisasi Sekolah. Cetakan I. Yogyakarta: Multi Presindo.

Sedarmayanti. 2011. Manajemen Sumber Daya Manusia, Reformasi Birokrasi dan Manajemen Pegawai Negeri Sipil (cetakan kelima). Bandung: PT Refika Aditama.

Danang, Sunyoto. 2012. Manajemen Sumber Daya Manusia. Jakarta: PT. Buku Seru.

Prihantoro, C. Rudy. 2012. Konsep Pengendalian Mutu, Bandung: PT. Remaja Rosdakarya Offset.

Yamin, Martinis dan Maisah. 2010. Standarisasi Kinerja Guru. Jakarta: Persada Press.

Sutikno. 2014. Pemimpin dan Kepemimpin: Tips Praktis untuk Menjadi Pemimpin yang diidolakan. Lombok: Holistica Lombo.

AA. Anwar Prabu Mangkunegara. 2013. Manajemen Sumber Daya Manusia Perusahaan. Bandung: Remaja Rosdakarya.

Siagian, Sondang. P. 2014. Manajemen Sumber Daya Manusia. Jakarta: Bumi Aksara.

Hasibuan, Malayu. 2012. Manajemen Sumber Daya manusia. Jakarta: PT Bumi Aksara.

Sugiyono. 2018. Metode Penelitian Kuantitatif. Bandung: Penerbit CV. Alfabeta.

Sugiyono. 2011. Metode Penelitian Kuantitatif, Kualitatif dan R\&D. Bandung: Afabeta.

Schultz, D \& Schultz, E. S. 2010. Psychology and work today (10 edition). New York: Pearson.

Hasibuan, Malayu S. P. 2016. Manajemen Sumber Daya Manusia. $\quad$ Edisi Revisi. Jakarta: Penerbit PT Bumi Aksara.

G.R. Terry. 2010. Manajemen Sumber Daya Manusia. Edisi Pertama. Cetakan Pertama. Jakarta: Penerbit Kencana.

Hasibuan, Malayu. 2013. Manajemen Sumber Daya Manusia. Jakarta: PT Bumi Aksara.

Marwansyah. 2014. Manajemen Sumber Daya Manusia. Bandung: Alfabeta.

Handoko, T. Hani. 2011. Manajemen Personalia dan Sumber Daya Manusia. Yogyakarta: Penerbit BPFE.

Nawawi. 2011. Manajemen Sumber Daya Manusia: Untuk Bisnis Yang Kompetitif. Yogyakarta: Gajahmada University Press,

Handoko, T. Hani, 2009. Manajemen Sumber Daya Manusia (Cetakan IX Jilid I). Yogyakarta: Penerbit BPFE.

Handoko, H. T. 2012. Manajemen Personalia dan Sumber Daya Manusia. BPFE: Yogyakarta.

Robbins SP, dan Judge. 2011. Perilaku Organisasi. Jakarta: Salemba Empat. 
Usman, Effendi. 2011. Asas Manajemen. Jakarta: PT. Raja Grafindo.

Rivai, Veithzal dan Deddy Mulyadi. 2012. Kepemimpinan dan Perilaku Organisasi Edisi Ketiga. Jakarta: PT. Raja Grafindo Persada.

Priyoto. 2014. Konsep Manajemen Stress. Yogyakarta: Nuha Medika

Ahmad Kuncoro Engkos dan Ridwan. 2017. Cara Menggunakan dan Memaknai Part Analisis (Analisis Jalur). Bandung: Alfabeta

Arsyad, Azhar. 2007. Media Pembelajaran. Jakarta: PT Raja Grafindo Persada

Rivai, Veithzal dan Sagala,Ella Jauvani. 2010. Manajemen Sumber Daya Manusia untuk Perusahaan dari Teori ke Praktik. Jakarta: PT Raja Grafindo.

Agung Dwi Saputra. 2014. "Pengaruh Stres dan Kondisi Fisik Lingkungan Kerja Terhadap Prestasi Kerja Karyawan CV. Daya Budaya Corporation Yogyakarta”.

Aldy pambudi Wicaksono. 2017. "Pengaruh Lingkungan kerja dan Stres Kerja terhadap Kinerja Karyawan Depot LPG Balongan PT. PERTAMINA (PERSERO)”.

Tri Wartono. 2017. "Pengaruh Stres kerja Terhadap Kinerja Karyawan (Studi Pada Karyawan Majalah Mother and Baby)".

Yulinda Rachmawati. 2011. "Pengaruh Kepemimpinan terhadap Stress Kerja Pada Bagian Operasional di CV. Delta Mina Jaya".

Imaniar Cahya Komala. 2013. "Pengaruh Gaya Kepemimpinan Terhadap Stres kerja Karyawan Pada karyawan Administrasi universitas Widyatama.”.

Erma Yulia dan Djudi Mukzam. 2017. "Pengaruh Gaya Kepemimpinan Terhadap Stres Kerja dan Kinerja Karyawan (Studi pada Karyawan PTPN XI Unit Usaha PG Semboro)”.

Muhammad Rizki, Djamhur Hamid dan Yuniadi. 2016. "Jurnal Administrasi Bisnis. Pengaruh Lingkungan kerja Terhadap Stres Kerja Karyawan (Studi Pada Karyawan PT PLN (Persero) Distribusi Jawa Timur Area PelayananMalang)".

Yosep Budi Prasetya. 2009. "Pengaruh Lingkungan Kerja Fisik dan Non Fisik Terhadap Tingkat Stres dan Kejenuhan Karyawan (Studi Kasus Divisi Operasional PT Primacom Interbuana Wisma".

Yulia Febriani Rahayu. 2014. "Pengaruh Lingkungan Kerja Fisik dan Lingkungan Kerja Fisik Non Fisik Terhadap Stres Kerja Karyawan Bagian Produksi Pada PJ. Muria Jaya Kudus".

Teddy Chandra dan Priyono. 2016. "Pengaruh Gaya Kepemimpinan, Lingkungan Kerja dan Kepuasan Kerja terhadap Kinerja Karyawan — Studi di Sekolah SMPN 10 Surabaya".

Reza Regina Aditya. 2013. Pengaruh Gaya Kepemimpinan, Motivasi, dan Disiplin Kerja terhadap Kinerja Karyawan PT. Sinar Santosa Perkasa Banjarnegara. Universitas Diponegoro, Semarang".

\section{Situs Website}


Data AISI. 2018. http://www.aisi.or.id/statistic/. Diakses 03 Desember 2018.

Data Yamaha. 2018. https://www.yamaha-motor.co.id/product/r25. Diakses 04 Desember 2018. 